\title{
Dibenzocyclooctadiene lignans from the fruits of Schisandra chinensis and their cytotoxicity on human cancer cell lines
}

\author{
Sung-Kyu Choi ${ }^{1 \dagger}$, Yeong-Geun Lee ${ }^{1 \dagger}$, Rong Bo Wang ${ }^{1}$, Hyoung-Geun Kim', Dahye Yoon², Dae Young Lee², \\ Yeon-Ju Kim ${ }^{1}$ and Nam-In Baek ${ }^{1 *}$
}

\begin{abstract}
Repeated chromatographic separations of the EtOAc fraction of Schisandra chinensis fruits on silica gel, octadecyl silica gel, and Sephadex LH-20 led to the isolation and identification of seven dibenzocyclooctadiene lignans (1-7). The NMR data reported in the literature for angeloyl gomisin $\mathrm{H} \mathrm{(5)}$ were shown to be incorrect. We unambiguously identified the compounds based on detailed analysis of the 1D and 2D NMR data, especially from HMBC and NOESY experiments. In addition, MTT assays and cell viability experiments verified the cytotoxicity of the isolated dibenzocyclooctadiene lignans against the human cancer cell lines AGS, HeLa, and HT-29.
\end{abstract}

Keywords: Angeloyl gomisin H, Cytotoxicity, Dibenzocyclooctadiene lignan, Human cancer cells, Schisandra chinensis

\section{Introduction}

Schisandra chinensis is a deciduous woody vine native to Far East Asia. The fruits, red berries called "Omija" in South Korea, have been used as food as well as a traditional medicine with hepaprotective, cardiovascular, and antibacterial benefits $[1,2]$. The Korean word Omija, meaning "five flavors" (sweet, sour, bitter, salty, and spicy), indicates that the fruit has a variety of components that exhibit pharmacological effects. To date, phytochemical studies of $S$. chinensis fruits have led to the isolation of lignans, triterpenoids, monoterpenes, sesquiterpenes, organic acids, and sterols, [3, 4] among which dibenzocyclooctadiene lignans are overwhelmingly the major components [5]. Among its major components, the NMR data reported in the literature for angeloyl gomisin $\mathrm{H}$ (5) were identified to be a little bit incorrect. Therefore, we

\footnotetext{
${ }^{*}$ Correspondence: nibaek@khu.ac.kr

'Sung-Kyu Choi and Yeong-Geun Lee made equal contributions to this work (co-first author)

${ }^{1}$ Graduate School of Biotechnology and Department of Oriental

Medicine Biotechnology, Kyung Hee University, Yongin 17104, Republic of Korea
}

Full list of author information is available at the end of the article unambiguously identified the compound $\mathbf{5}$ to correct its NMR value based on detail NMR analysis technics especially gHMBC and NOESY. Also, S. chinensis extracts and some dibenzocyclooctadiene lignans from this plant have been reported to be cytotoxic to certain cancer cell lines [6-9]. Despites their significant anti-cancer effects, there has been no report concerning their chemical structures relationship between their cytotoxic activity against various cancer cells.

This paper describes the isolation for seven dibenzocyclooctadiene lignans from the fruits of $S$. chinensis, structure determination of the isolation ones, especially angeloyl gomisin $\mathrm{H}(5)$. In addition, their cytotoxicities were evaluated against several human cancer cell lines (AGS, HeLa, and HT-29), and the relationship of their structure to their activity.

\section{Materials and methods}

\section{General experimental procedures}

The instruments and chemicals used in these experiments were prepared according to previous studies [10-12]. 


\section{Plant materials}

Schisandra chinensis fruits were provided by RDA, Eumseong, Korea, in 2019 and identified by Prof. DaeKeun Kim, Woo Suk Univ., Jeonju, Korea. A voucher specimen (KHU-NPCL-201904) has been stored in Prof Nam-In Baek's Laboratory.
Extraction and isolation of dibenzocyclooctadiene lignans

The dried fruits of $S$. chinensis $(5.4 \mathrm{~kg})$ were soaked in $70 \%$ aqueous $\mathrm{EtOH}(54 \mathrm{~L} \times 3)$ at room temperature for $24 \mathrm{~h}$. After filtration, the extract was concentrated to afford $1.3 \mathrm{~kg}$ of crude material. The obtained concentrate was suspended in $\mathrm{H}_{2} \mathrm{O}(4.2 \mathrm{~L})$ and sequentially

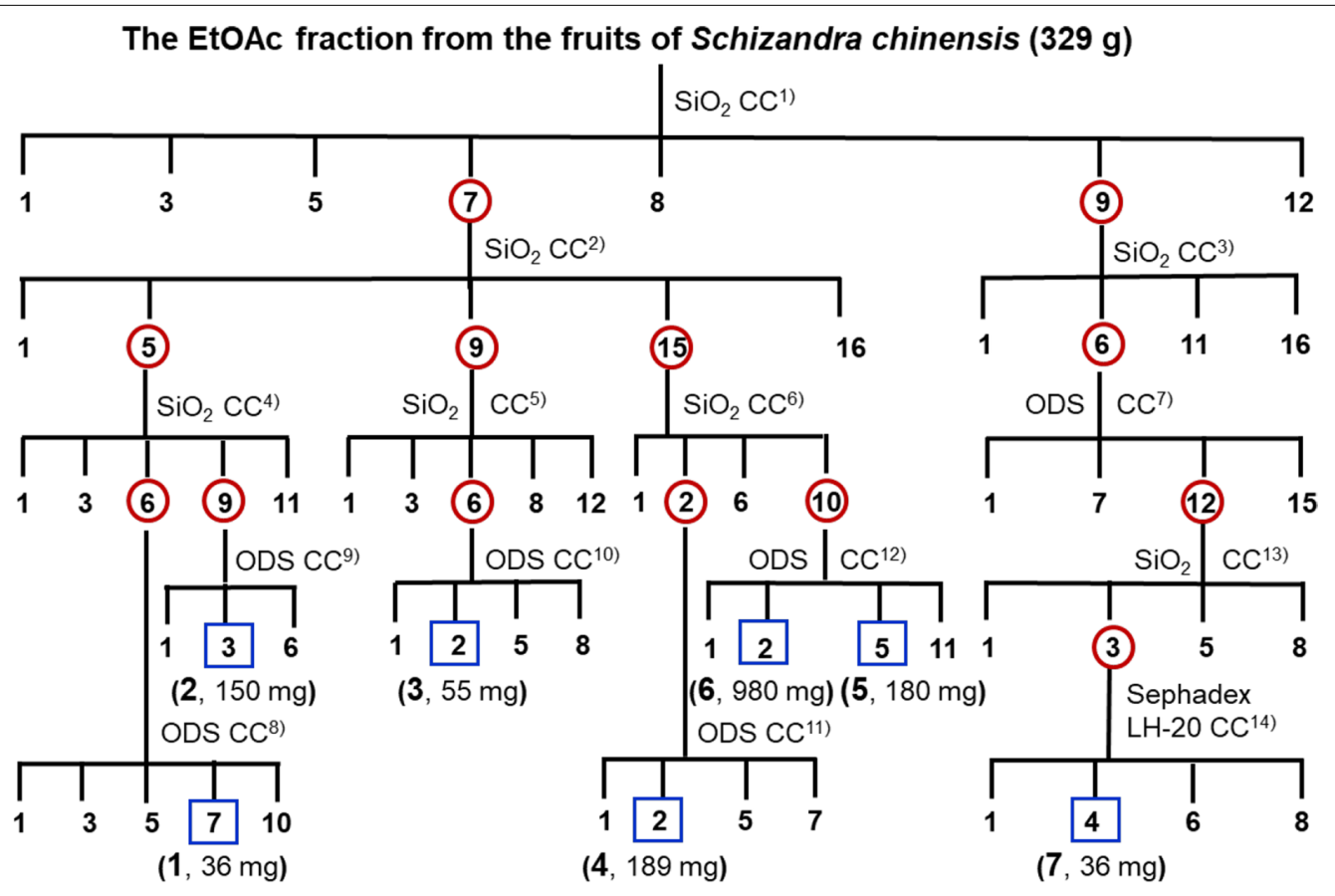

1) $329 \mathrm{~g}, \varnothing 11 \times 16 \mathrm{~cm} / \mathrm{n}$-hexane:EtOAc $=15: 1 \rightarrow 10: 1 \rightarrow 5: 1 \rightarrow 1: 1$ (7.8 L of each )

2) $36 \mathrm{~g}, \varnothing 7.5 \times 17 \mathrm{~cm} / n$-hexane:EtOAc=5:1 (23.8 L)

3) $27 \mathrm{~g}, \varnothing 7.5 \times 16 \mathrm{~cm} / n$-hexane:EtOAc=3:1 $\rightarrow 2: 1 \rightarrow 1: 1$ (5.3 L of each )

4) $3.1 \mathrm{~g}, \varnothing 4 \times 21 \mathrm{~cm} / \mathrm{CHCl}_{3}:$ EtOAc $=20: 1 \rightarrow 15: 1(3.3 \mathrm{~L})$

5) $3.8 \mathrm{~g}, \varnothing 4.5 \times 17 \mathrm{~cm} / \mathrm{CHCl}_{3}:$ EtOAc=20:1 $\rightarrow 15: 1 \rightarrow 7: 1$ (2.5 L of each )

6) $6.4 \mathrm{~g}, \varnothing 7 \times 17 \mathrm{~cm} / \mathrm{CHCl}_{3}:$ EtOAc $=10: 1 \rightarrow 5: 1 \rightarrow 1: 1(5.3 \mathrm{~L}$ of each )

7) $1.6 \mathrm{~g}, \varnothing 5.5 \times 9 \mathrm{~cm} /$ acetone: $\mathrm{H}_{2} \mathrm{O}=1: 1(1.3 \mathrm{~L})$

8) $200 \mathrm{mg}, \varnothing 2.5 \times 7 \mathrm{~cm} /$ acetone: $\mathrm{H}_{2} \mathrm{O}=3: 2(600 \mathrm{~mL})$

9) $380 \mathrm{mg}, \varnothing 3 \times 6 \mathrm{~cm} /$ acetone: $\mathrm{H}_{2} \mathrm{O}=1: 1(700 \mathrm{~mL})$

10) $385 \mathrm{mg}, \varnothing 3 \times 10 \mathrm{~cm} /$ acetone: $\mathrm{H}_{2} \mathrm{O}=1: 1(800 \mathrm{~mL})$

11) $280 \mathrm{mg}, \varnothing 3 \times 10 \mathrm{~cm} /$ acetone: $\mathrm{H}_{2} \mathrm{O}=1: 1(900 \mathrm{~mL})$

12) $1.2 \mathrm{~g}, \varnothing 3 \times 10 \mathrm{~cm} /$ acetone: $\mathrm{H}_{2} \mathrm{O}=1: 1(1,000 \mathrm{~mL})$

13) $788 \mathrm{mg}, \varnothing 3 \times 16 \mathrm{~cm} / \mathrm{n}$-Hexane:EtOAc=3:1 (2,000 mL)

14) $112 \mathrm{mg}, \varnothing 1.5 \times 55 \mathrm{~cm} / \mathrm{MeOH}(300 \mathrm{~mL})$

Fig. 1 Isolation of dibenzocyclooctadiene lignans from Schisandra chinensis fruit. $\mathrm{SiO}_{2}$ : silica gel; ODS: octadecyl-silica gel; CC: column chromatography 
washed with EtOAc $(4.2 \mathrm{~L} \times 3)$ and $n-\mathrm{BuOH}(3.4 \mathrm{~L} \times 3)$. The partitioned extracts were concentrated to obtain the EtOAc (SCE, $329 \mathrm{~g}$ ), $n-\mathrm{BuOH}$ (SCB, $247 \mathrm{~g}$ ), and $\mathrm{H}_{2} \mathrm{O}$ (SCW, $723 \mathrm{~g}$ ) fractions. SCE (329 g) was applied to a $\mathrm{SiO}_{2}$ column chromatography (c.c.) (Fig. 1), and the eluate was monitored using TLC and separated into 12 (SCE-1-SCE-12) fractions. Subsequent c.c. separations of fractions 7 (SCE-7) and 9 (SCE-9) using $\mathrm{SiO}_{2}$, ODS, and Sephadex LH-20 were carried out (Fig. 1) to yield seven purified lignans, 1-7.

Schisandrin A (1): colorless solid; $[\alpha]_{\mathrm{D}}^{25}+128^{\circ}(c 0.8$, $\mathrm{MeOH}$ ); IR (LiF plate, v) 2947, 1651, $1459 \mathrm{~cm}^{-1}$; EIMS $m / z 416[\mathrm{M}]^{+} ;{ }^{1} \mathrm{H}$ and ${ }^{13} \mathrm{C}$ NMR spectroscopic data, see Additional file 1: Table S1.

(-)-Gomisin K1 (2): colorless solid, $[\alpha]_{\mathrm{D}}^{25}-98^{\circ}$ (c 0.2, $\mathrm{CHCl}_{3}$ ); IR (LiF plate, v) 3420, 2930, 1582, $1496 \mathrm{~cm}^{-1}$; EIMS $m / z 402[\mathrm{M}]^{+} ;{ }^{1} \mathrm{H}$ and ${ }^{13} \mathrm{C}$ NMR spectroscopic data, see Additional file 1: Table S2.

Gomisin J (3): colorless solid; $[\alpha]_{\mathrm{D}}^{25}-38^{\circ}(c$ 0.6, acetone); IR (LiF plate, v) 3426, 2920, 1583, $1458 \mathrm{~cm}^{-1}$; EIMS $m / z 388[\mathrm{M}]^{+} ;{ }^{1} \mathrm{H}$ and ${ }^{13} \mathrm{C}$ NMR spectroscopic data, see Additional file 1: Table S3.

Gomisin A (4): colorless solid; $[\alpha]_{\mathrm{D}}^{25}+71^{\circ}$ (c 0.7 , $\mathrm{CHCl}_{3}$ ); IR (LiF plate, v) 3332, 2947, $1647 \mathrm{~cm}^{-1}$; EIMS $m / z 416[\mathrm{M}]^{+} ;{ }^{1} \mathrm{H}$ and ${ }^{13} \mathrm{C}$ NMR spectroscopic data, see Additional file 1: Table S4.

Angeloyl gomisin $\mathrm{H}(\mathbf{5})$ : colorless solid, $[\alpha]_{\mathrm{D}}^{25}+17^{\circ}$ (c 1.1, $\mathrm{CHCl}_{3}$ ); IR (LiF plate, v) 2953, 1733, 1596, $1457 \mathrm{~cm}^{-1}$; EIMS $m / z 500[\mathrm{M}]{ }^{+} ;{ }^{1} \mathrm{H}$ and ${ }^{13} \mathrm{C}$ NMR spectroscopic data, see Table 1.

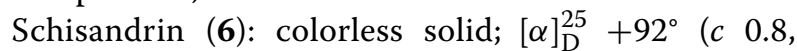
$\mathrm{CHCl}_{3}$ ); IR (LiF plate, v) 3420, 2934, 1594, $1456 \mathrm{~cm}^{-1}$; EIMS $m / z 432[\mathrm{M}]^{+} ;{ }^{1} \mathrm{H}$ and ${ }^{13} \mathrm{C}$ NMR spectroscopic data, see Additional file 1: Table S5.

Gomisin C (7): colorless solid; $[\alpha]_{\mathrm{D}}^{25}-132^{\circ}$ (c 0.6, $\mathrm{CHCl}_{3}$ ); IR (LiF plate, $v$ ) 3502, 2923, $1720,1595 \mathrm{~cm}^{-1}$; EIMS $m / z 536[\mathrm{M}]^{+} ;{ }^{1} \mathrm{H}$ and ${ }^{13} \mathrm{C}$ NMR spectroscopic data, see Additional file 1: Table S6.

\section{Cell viability assay}

Cell reasonability was dictated by MTT measure as recently portrayed [13]. Cells were seeded at a thickness of $1 \times 10^{3}$ cells/well in a 96-well plate and refined with sans serum DMEM or RPMI-1640 for $16 \mathrm{~h}$. At that point, the cells were treated with sequential groupings of Angeloyl gomisin H, Gomisin A, Gomisin C, Gomisin J, (-)- Gomisin K1, Schisandrin, in different concentration $(10,25,50 \mu \mathrm{g} / \mathrm{mL})$ for $24 \mathrm{~h}$. Treatment at every fixation was acted in triplicate. After medicines, the medium was suctioned and cells were washed with PBS. Cells were in this manner hatched with MTT arrangement $(5 \mathrm{mg} / \mathrm{mL}$ ) for $6 \mathrm{~h}$. The supernatant was expelled, and formazan was solubilized in isopropanol and estimated spectrophotometrically at $570 \mathrm{~nm}$. The level of practical cells was assessed in examination with untreated cells. The information shows the mean $\pm \mathrm{SD}$ of at least three free trials.

\section{Hoechst 33258 and propidium iodide staining}

All the cells were seeded onto amplifying instrument coverslip in a 6-well plate until further notice and were treated with $\mathrm{IC}_{50}$ union of ginger blends. In the wake of washing twice with PBS, cells were fixed with $4 \%$ paraformaldehyde for $15 \mathrm{~min}$. The joined cells were recolored with $500 \mu \mathrm{L}$ Hoechst $33258(5 \mu \mathrm{g} / \mathrm{mL})$ plan and $500 \mu \mathrm{L}$ propidium iodide (PI, $5 \mu \mathrm{g} / \mathrm{mL}$ ) course of action at room temperature for $30 \mathrm{~min}$, exclusively. Apoptotic cells with combined and partitioned centers were overviewed using

\section{Table $1{ }^{1} \mathrm{H}$ and ${ }^{13} \mathrm{C}$ NMR data of angeloyl gomisin $\mathrm{H}$ (5)} (600 $\mathrm{MHz}, \mathrm{CDCl}_{3}$ )

\begin{tabular}{|c|c|c|}
\hline No of $C$ & $\delta_{H}$ & $\delta_{c}$ \\
\hline 1 & & 151.70 \\
\hline 2 & & 140.31 \\
\hline 3 & & 152.57 \\
\hline 4 & $6.52,1 \mathrm{H}, \mathrm{s}$ & 110.17 \\
\hline 5 & & 133.15 \\
\hline 6 & $\begin{array}{l}2.70,1 \mathrm{H}, \mathrm{d}, J=13.8 \mathrm{~Hz} \\
2.30,1 \mathrm{H}, \mathrm{d}, J=13.8 \mathrm{~Hz}\end{array}$ & 40.69 \\
\hline 7 & & 72.05 \\
\hline 8 & $1.83,1 \mathrm{H}, \mathrm{m}$ & 41.94 \\
\hline 9 & $\begin{array}{l}\text { 2.67, } 1 \mathrm{H}, \text { br. } d, J=13.8 \mathrm{~Hz} \\
2.37,1 \mathrm{H}, \mathrm{dd}, J=13.8,7.2 \mathrm{~Hz}\end{array}$ & 34.29 \\
\hline 10 & & 133.91 \\
\hline 11 & $6.66,1 \mathrm{H}, \mathrm{s}$ & 112.77 \\
\hline 12 & & 151.78 \\
\hline 13 & & 139.66 \\
\hline 14 & & 142.27 \\
\hline 15 & & 123.22 \\
\hline 16 & & 122.85 \\
\hline 17 & $0.81,3 \mathrm{H}, \mathrm{d}, J=7.2 \mathrm{~Hz}$ & 15.90 \\
\hline 18 & $1.20,3 \mathrm{H}, \mathrm{s}$ & 29.89 \\
\hline 1-OMe & $3.50,3 \mathrm{H}, \mathrm{s}$ & 60.63 \\
\hline 2-OMe & $3.79,3 \mathrm{H}, \mathrm{s}$ & 60.79 \\
\hline 3-OMe & $3.83,3 \mathrm{H}, \mathrm{s}$ & 56.04 \\
\hline 12-OMe & $3.86,3 \mathrm{H}, \mathrm{s}$ & 56.04 \\
\hline 13-OMe & $3.79,3 \mathrm{H}, \mathrm{s}$ & 60.79 \\
\hline Angeloyl-1' & & 165.89 \\
\hline Angeloyl-2' & & 127.63 \\
\hline Angeloyl-3' & $5.85,1 \mathrm{H}, \mathrm{q}, J=7.2 \mathrm{~Hz}$ & 137.38 \\
\hline Angeloyl-4' & $1.72,3 \mathrm{H}, \mathrm{d}, J=7.2 \mathrm{~Hz}$ & 15.31 \\
\hline Angeloyl-5' & $1.71,3 \mathrm{H}, \mathrm{s}$ & 20.33 \\
\hline
\end{tabular}



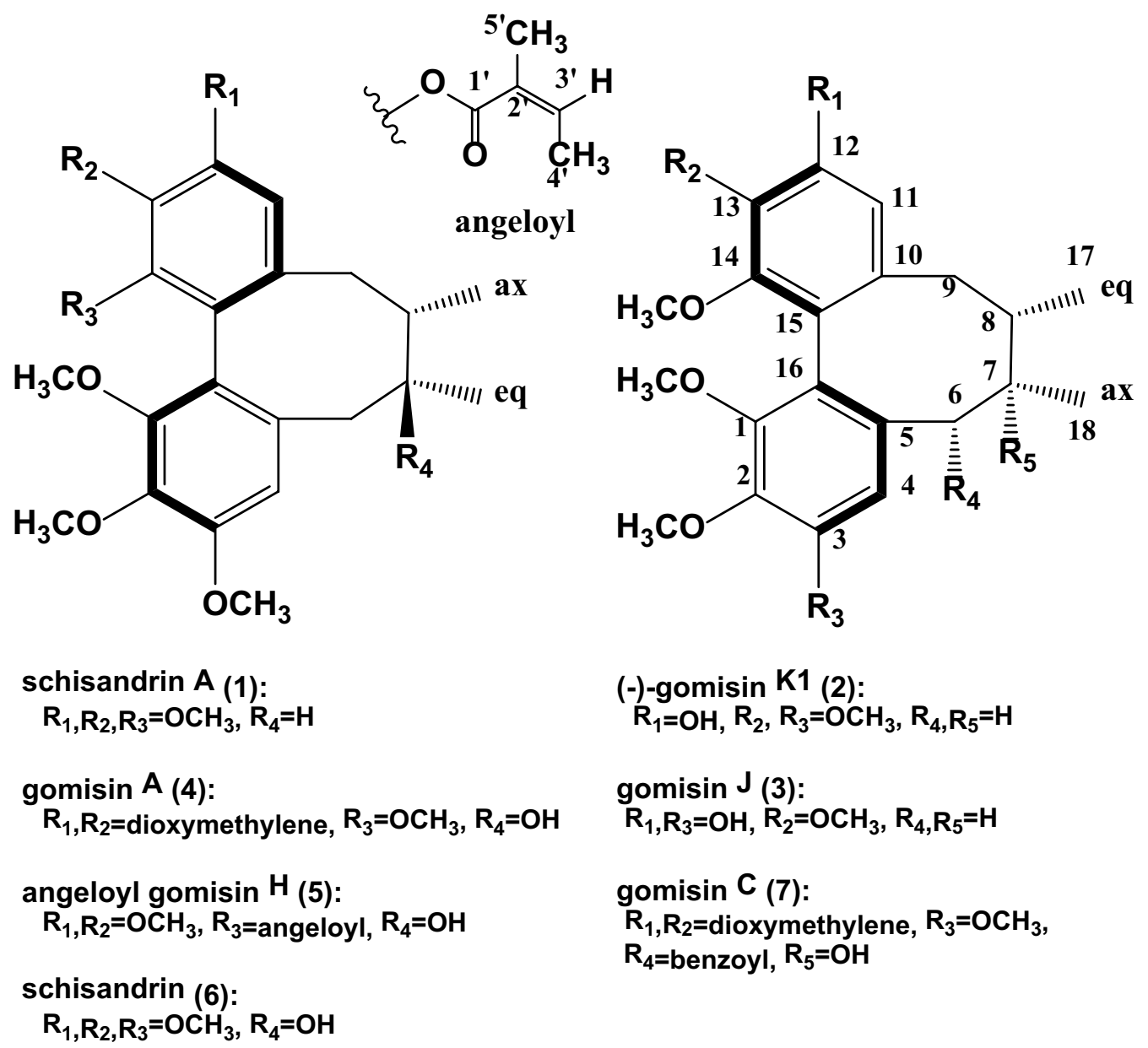

(-)-gomisin $\mathrm{K} 1$ (2):

$\mathrm{R}_{1}=\mathrm{OH}, \mathrm{R}_{2}, \mathrm{R}_{3}=\mathrm{OCH}_{3}, \mathbf{R}_{4}, \mathrm{R}_{5}=\mathrm{H}$

gomisin $\mathbf{J}(3)$ :

$\mathrm{R}_{1}, \mathrm{R}_{3}=\mathrm{OH}, \mathrm{R}_{\mathbf{2}}=\mathrm{OCH}_{3}, \mathbf{R}_{\mathbf{4}}, \mathrm{R}_{\mathbf{5}}=\mathrm{H}$

gomisin C (7):

$\mathbf{R}_{1}, \mathbf{R}_{2}=$ dioxymethylene, $\mathbf{R}_{\mathbf{3}}=\mathrm{OCH}_{3}$, $\mathbf{R}_{\mathbf{4}}=$ benzoyl, $\mathbf{R}_{\mathbf{5}}=\mathrm{OH}$

$\mathbf{R}_{1}, \mathbf{R}_{2}, \mathbf{R}_{3}=\mathrm{OCH}_{3}, \mathbf{R}_{4}=\mathrm{OH}$

Fig. 2 Chemical structures of dibenzocyclooctadiene lignans from Schisandra chinensis fruit

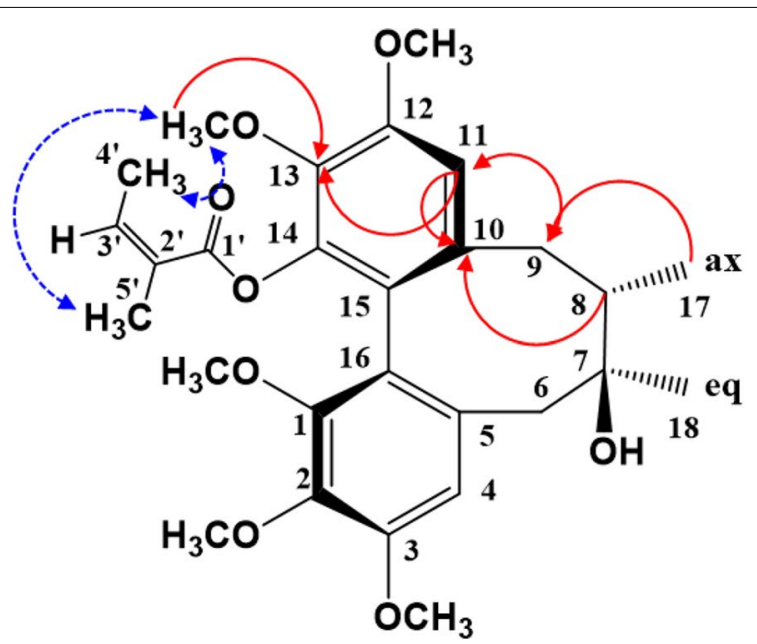

gHMBC

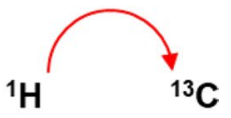

NOESY

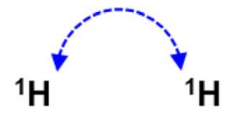

Fig. 3 Selected key gHMBC and NOESY correlations in angeloyl gomisin $\mathrm{H}$ (5) 
a Leica DMLB fluorescence amplifying focal point (Wetzlar, Germany) [14, 15].

\section{Results and discussion}

Dried S. chinensis fruits were extracted with aqueous $\mathrm{EtOH}$, and the concentrated extract was partitioned into EtOAc, $n-\mathrm{BuOH}$, and $\mathrm{H}_{2} \mathrm{O}$. Repeated separations of the EtOAc fraction by $\mathrm{SiO}_{2}$, ODS, and Sephadex LH-20 c.c. led to the isolation of dibenzocyclooctadiene-type lignans 1-7, identified as schisandrin A (1), [16] (-)-gomisin K1 (2), [17] gomisin J (3), [6] gomisin A (4), [6, 17] angeloyl gomisin $H(5),[2,17,18]$ schisandrin $(6),[6,19,20]$ and gomisin $C$ (7) [17] through detailed analysis of the spectroscopic data from 1D and 2D NMR and IR spectroscopy, FAB/MS, and specific rotation data as well as comparison with the data in the literature (Fig. 2). Of the seven compounds, The NMR data reported in the literatures for angeloyl gomisin $\mathrm{H}(5)$ were identified to be a little bit incorrect $[2,4,13,17,18]$.

Compound 5, a colorless powder, showed UV absorptions at 254 and $365 \mathrm{~nm}$ and developed a yellowish color after spraying with $10 \% \mathrm{H}_{2} \mathrm{SO}_{4}$ and heating. Its IR spectrum suggested the presence of carbonyl $\left(1733 \mathrm{~cm}^{-1}\right)$ and conjugated double bonds (1596 and $\left.1457 \mathrm{~cm}^{-1}\right)$. Its molecular weight was determined to be $500 \mathrm{Da}$ from the molecular ion peak $m / z 500[\mathrm{M}]^{+}$in the EIMS. The ${ }^{1} \mathrm{H}$ NMR spectrum (Table 1) exhibited signals typical of a dibenzocyclooctadiene lignan moiety, two aromatic methines $\left(\delta_{\mathrm{H}} 6.66,1 \mathrm{H}, \mathrm{s}, \mathrm{H}-11 ; \delta_{\mathrm{H}} 6.52,1 \mathrm{H}, \mathrm{s}, \mathrm{H}-4\right)$, two methylenes with germinal coupling $\left(\delta_{\mathrm{H}} 2.70,1 \mathrm{H}, \mathrm{d}\right.$, $J=13.8 \mathrm{~Hz}, \mathrm{H}-6 \mathrm{a} ; \delta_{\mathrm{H}} 2.30,1 \mathrm{H}, \mathrm{d}, J=13.8 \mathrm{~Hz}, \mathrm{H}-6 \mathrm{~b} ; \delta_{\mathrm{H}}$ $2.67,1 \mathrm{H}$, br. d, $J=13.8 \mathrm{~Hz}, \mathrm{H}-9 \mathrm{a} ; \delta_{\mathrm{H}} 2.37,1 \mathrm{H}, \mathrm{dd}, J=13.8$, $7.2 \mathrm{~Hz}, \mathrm{H}-9 \mathrm{~b})$, one methine $\left(\delta_{\mathrm{H}} 1.83,1 \mathrm{H}, \mathrm{m}, \mathrm{H}-8\right)$, two methyl groups $\left(\delta_{\mathrm{H}} 1.20,3 \mathrm{H}, \mathrm{s}, \mathrm{H}-18 ; \delta_{\mathrm{H}} 0.81,3 \mathrm{H}, \mathrm{d}\right.$, $J=7.2 \mathrm{~Hz}, \mathrm{H}-17)$, and five methoxy groups $\left(\delta_{\mathrm{H}} 3.50\right.$, $3 \mathrm{H}, \mathrm{s}, \mathrm{H}-1-\mathrm{OMe} ; \delta_{\mathrm{H}} 3.79,3 \mathrm{H}, \mathrm{s}, \mathrm{H}-2-\mathrm{OMe} ; \delta_{\mathrm{H}} 3.83,3 \mathrm{H}$, s, H-3-OMe; $\delta_{\mathrm{H}} 3.86,3 \mathrm{H}, \mathrm{s}, \mathrm{H}-12-\mathrm{OMe} ; \delta_{\mathrm{H}} 3.79,3 \mathrm{H}, \mathrm{s}$, $\mathrm{H}-13-\mathrm{OMe})$. In addition, one olefin methine $\left(\delta_{\mathrm{H}} 5.85,1 \mathrm{H}\right.$, q, $J=7.2 \mathrm{~Hz}, \mathrm{H}$-angeloyl-1') and two allylic methyl groups $\left(\delta_{\mathrm{H}} 1.72,3 \mathrm{H}, \mathrm{d}, J=7.2 \mathrm{~Hz}, \mathrm{H}\right.$-angeloyl-4'; $\delta_{\mathrm{H}} 1.71,3 \mathrm{H}, \mathrm{s}$, $\mathrm{H}$-angeloyl-5') were observed, indicating a 2-methyl-but2 -enoyl substituent $[17,18,21]$. The chemical shifts and coupling patterns confirmed that the organic acid moiety was not tiglic acid but angelic acid because the chemical shifts of the olefin methine proton signal for tiglic acid with the $Z$-configuration and angelic acid with the $E$-configuration are $\delta_{\mathrm{H}} 6.78$ and $\delta_{\mathrm{H}} 5.88$, respectively, and the two methyl carbon signals were also consistent with this assignment (angeloyl, $\delta_{\mathrm{C}} 21,16$; tigloyl, $\delta_{\mathrm{C}} 12,14$ ) $[17,18,21]$. methoxy proton signals for methoxy groups at $\mathrm{C}-1$ or $\mathrm{C}-14$ are usually observed more upfield, $\delta_{\mathrm{H}}$ 3.50 , compared to those at C-2, C-3, C-12, and C-13, $\delta_{\mathrm{H}}$
3.79 to 3.86 [21]. Therefore, four of the methoxy groups were confirmed to be located at C-2, C-3, C-12, and $\mathrm{C}-13$ and another was present at $\mathrm{C}-1$ or $\mathrm{C}-14$. The position of the hydroxyl group on the cyclooctane ring was determined to be $\mathrm{C}-7$ because $\mathrm{CH}_{3}-17$ was observed as a doublet, while $\mathrm{CH}_{3}-18$ was a singlet. Taken together, these results suggest that compound $\mathbf{5}$ is a dibenzocyclooctadiene lignan with four methoxy groups at $\mathrm{C}-2$, $\mathrm{C}-3, \mathrm{C}-12$, and $\mathrm{C}-13$; a hydroxyl and an angeloyl group at $\mathrm{C}-1$ and $\mathrm{C}-14$; and another hydroxyl group at $\mathrm{C}-7$. The two benzene rings are positioned in an $R$-biphenyl configuration [5] (Fig. 2). The ${ }^{13} \mathrm{C}$ NMR spectrum also showed signals indicative of a dibenzocyclooctadiene derivative with a hydroxyl group at $\mathrm{C}-7$, six oxygenated aromatic quaternary carbons $\left(\delta_{\mathrm{C}} 152.57, \mathrm{C}-3 ; \delta_{\mathrm{C}} 151.78\right.$, $\mathrm{C}-12 ; \delta_{\mathrm{C}} 151.70, \mathrm{C}-1 ; \delta_{\mathrm{C}} 142.27, \mathrm{C}-14 ; \delta_{\mathrm{C}} 140.31, \mathrm{C}-2$; $\left.\delta_{\mathrm{C}} 139.66, \mathrm{C}-13\right)$, four aromatic quaternary carbons $\left(\delta_{\mathrm{C}}\right.$ $133.91, \mathrm{C}-10 ; \delta_{\mathrm{C}} 133.15, \mathrm{C}-5 ; \delta_{\mathrm{C}} 123.22, \mathrm{C}-15 ; \delta_{\mathrm{C}} 122.85$, $\mathrm{C}-4)$, two aromatic methines $\left(\delta_{\mathrm{C}} 112.77, \mathrm{C}-12 ; \delta_{\mathrm{C}} 110.17\right.$, $\mathrm{C}-4)$, one oxygenated quaternary carbon $\left(\delta_{\mathrm{C}} 72.05, \mathrm{C}-7\right)$, one methine $\left(\delta_{\mathrm{C}} 41.94, \mathrm{C}-8\right)$, two methylenes $\left(\delta_{\mathrm{C}} 40.94\right.$, C-6; $\left.\delta_{\mathrm{C}} 34.29, \mathrm{C}-9\right)$, two methyl carbons $\left(\delta_{\mathrm{C}} 29.89, \mathrm{C}-18\right.$; $\left.\delta_{\mathrm{C}} 15.90, \mathrm{C}-17\right)$, and five methoxy carbons $\left(\delta_{\mathrm{C}} 60.63\right.$, C-1-OMe; $\delta_{\mathrm{C}} 60.79, \mathrm{C}-2-\mathrm{OMe} ; \delta_{\mathrm{C}} 56.04, \mathrm{C}-3-\mathrm{OMe} ; \delta_{\mathrm{C}}$ 56.04, C-12-OMe; $\left.\delta_{\mathrm{C}} 60.79, \mathrm{C}-13-\mathrm{OMe}\right)$. In addition, signals indicative of an angeloyl moiety, namely, one ester $\left(\delta_{\mathrm{C}} 165.89, \mathrm{C}\right.$-angeloyl-1' $)$, one olefinic quaternary carbon $\left(\delta_{\mathrm{C}} 127.63\right.$, C-angeloyl-2'), one olefinic methine $\left(\delta_{\mathrm{C}}\right.$ 137.38 , C-angeloyl-3'), and two methyl groups $\left(\delta_{\mathrm{C}} 20.33\right.$, C-angeloyl-5'; $\delta_{\mathrm{C}} 15.31, \mathrm{C}$-C-angeloyl-4'), were observed. However, the position of the angeloyl moiety remains undefined. The HMBC experiment offers no solution because it provides long-range correlations via $J^{2}$ or $J^{3}$, in general. The NOESY experiment alternatively provided proof that the organic acid was on $\mathrm{C}-1$ or $\mathrm{C}-14$. The two allylic methyl proton signals $\left(\delta_{\mathrm{H}} 1.72, \mathrm{H}\right.$-angeloyl-4'; $\delta_{\mathrm{H}}$

\section{Table 2 Inhibitory effects of dibenzocyclooctadiene lignans (1-7) from Schisandra chinensis fruit on the growth of AGS, HeLa, and HT29 cells}

\begin{tabular}{|c|c|c|c|c|}
\hline \multirow[t]{2}{*}{ Compound } & \multicolumn{4}{|l|}{ IC50 ( $\mu \mathrm{M})$} \\
\hline & AGS & Hela & HT29 & Raw264.7 \\
\hline 1 & - & - & - & $4.43 \pm 0.24$ \\
\hline 2 & - & $5.46 \pm 0.24$ & - & $7.03 \pm 0.22$ \\
\hline 3 & - & $6.51 \pm 0.26$ & - & $6.54 \pm 0.14$ \\
\hline 4 & $14.81 \pm 1.02$ & $13.76 \pm 0.38$ & - & $17.51 \pm 0.64$ \\
\hline 5 & $12.94 \pm 0.12$ & $9.36 \pm 0.39$ & $7.94 \pm 0.19$ & $15.18 \pm 0.91$ \\
\hline 6 & - & - & - & $15.42 \pm 0.59$ \\
\hline 7 & - & - & - & $3.22 \pm 0.09$ \\
\hline
\end{tabular}

AGS: human stomach adenocarcinoma cells; Hela: human cervical cancer cells; HT29: human colon cancer cells; Raw264.7: Murine macrophage cells 

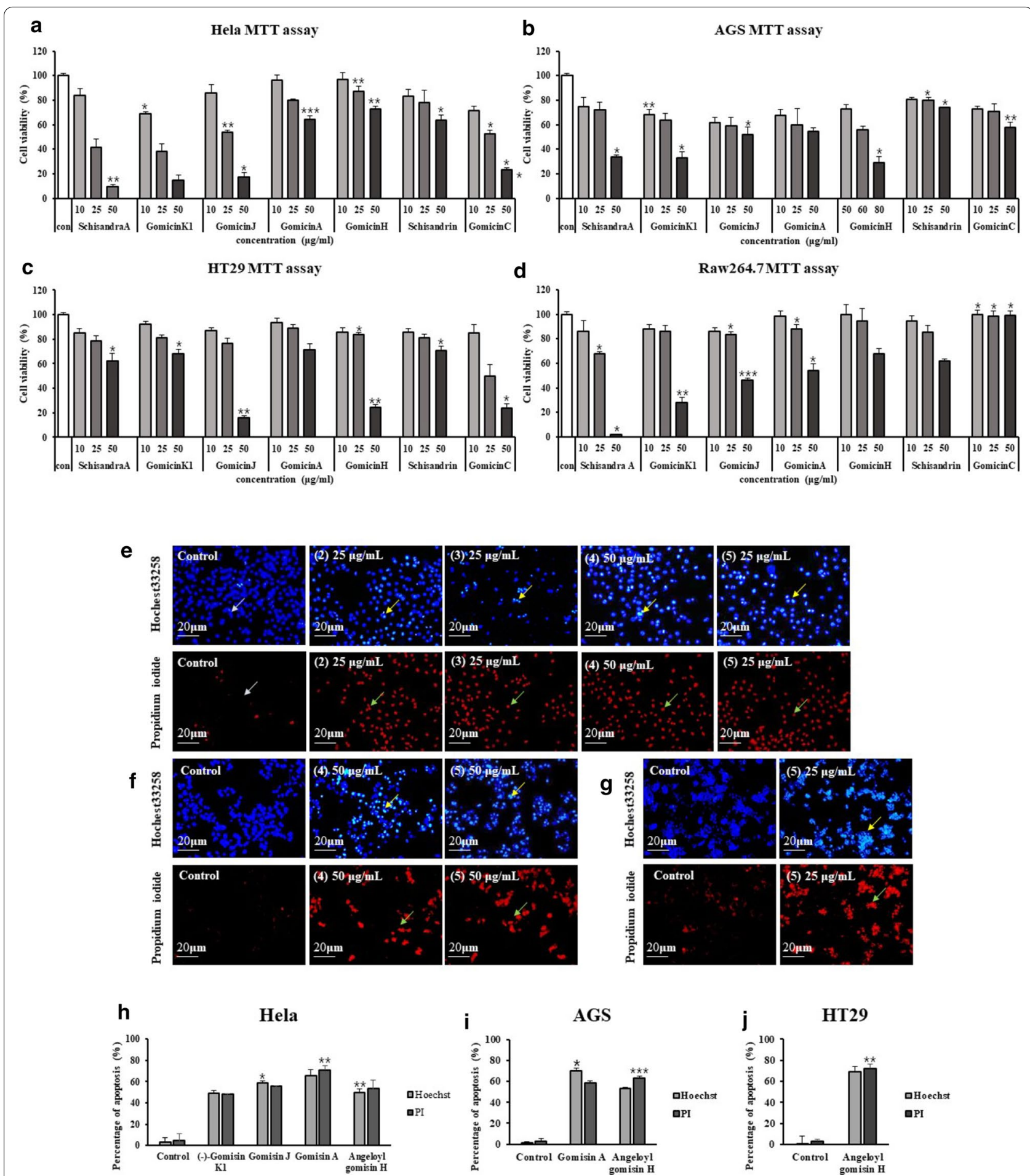

Fig. 4 Cell viability of Hela, AGS, HT29, Raw264.7 cells and cancer cells staining after treatment with different concentration of compounds for $24 \mathrm{~h}$. Cell viability was measured by MTT assay a Hela Cell, b AGS Cell, $\mathbf{c}$ HT29, d Raw264.7. Effect of dibenzocyclooctadiene lignans from Schisandra chinensis fruit on the activation of apoptosis in HeLa (e), AGS (f), and HT-29 (g) cells. Hoechst staining was used to detect nuclear condensation of treated and untreated cells. Propidium iodide (PI) staining was used to measure the cell death caused by treatment with the compounds. The white arrows show the unstained cell, the yellow and green arrows show the necrotic and apoptotic cells. The percentage of apoptosis were showed in $\mathbf{h}$, $\mathbf{i}$ and $\mathbf{j}$ 
1.71, $\mathrm{H}$-angeloyl- $\left.5^{\prime}\right)$ of the angeloyl moiety showed NOE correlations with the methoxy proton signal $\left(\delta_{\mathrm{H}} 3.79\right.$, $\mathrm{H}-13-\mathrm{OMe})$, which was already identified as $\mathrm{OCH}_{3}-13$ from the cross peak between $\mathrm{H}-11\left(\delta_{\mathrm{H}} 6.66\right)$ and $\mathrm{C}-13\left(\delta_{\mathrm{C}}\right.$ $151.78)$ in the HMBC spectrum. Ultimately, compound 5 was identified as angeloyl gomisin $\mathrm{H}$ (Fig. 3), and all the NMR data were unequivocally assigned.

Schisandra chinensis extract and major components from this plant are previously reported to have an anticancer activity including cytotoxicity on human cancer cell lines [22]. Especially almost compounds which have dibenzocylooctadiene-type lignans structure, deoxyschisandrin, gomisin A, and $\gamma$-schisandrin, have significant anti-cancer effect [23-26]. However, there are no reports for the cytotoxicity of dibenzocylooctadienetype lignans on gastric (AGS), cervical (HeLa), and colon (HT-29) human cancer cells. Therefore, we evaluated the dibenzocylooctadiene lignans (1-7) from $S$. chinensis fruits for the cytotoxicity of the human cancer cells using MTT assay.

Accordingly, to investigate the cytotoxic effects of lignans 1-7, we examined their effects on the viability of AGS, HeLa, HT-29, and RAW 264.7 cells (Table 2 and Fig. 4). The lignans were screened for their cytotoxic effects on RAW 264.7 cells at various concentrations ranging from 10 to $100 \mu \mathrm{g} / \mathrm{mL}$ for $24 \mathrm{~h}$ using an MTT assay. Results of MTT assay are presented as the mean \pm standard deviation of three independent experiments. The MTT assay showed that compounds 2-5, especially angeloyl gomisin $H(5)$, concentrationdependently suppressed the proliferation and viability against three cancer cells. Even though $\mathrm{IC}_{50}$ in $\mathrm{AGS}$ $(22.01 \pm 1.87 \mu \mathrm{M})$, HeLa $(32.68 \pm 2.21 \mu \mathrm{M})$, and HT29 $(156.04 \pm 6.71 \mu \mathrm{M})$ cells were low relative to those of the well-known and clinically used anticancer compound doxorubicin's $\mathrm{IC}_{50}$ value (AGS, $0.25 \mu \mathrm{M}$; HeLa, $1.45 \pm 0.15$ or $3.7 \pm 0.3 \mu \mathrm{M}$; HT29, 11.39 or $0.75 \mu \mathrm{M}$ ), [27-31] the $\mathrm{IC}_{50}$ values are very high in comparison to naturally occurring compounds (baicalein on AGS, $85 \mu \mathrm{M}$; galactosyl diglyceride on AGS, $49-83 \mu \mathrm{M}$; clausenidin on HT29, $42 \mu \mathrm{M}$; quercetin on HT29, $75 \mu \mathrm{M}$ ) [30-33].

Compounds 4-6, which have a hydroxy group at C-7, showed relatively weak toxicity on RAW 264.7 cells compared with lignans without a hydroxyl group at C-7. In comparison, compounds $\mathbf{2 , 3}$, and 7 , which have $S$-biphenyl positions, and compound $\mathbf{1}$, in which all the hydroxy groups in the benzene ring are substituted by methoxy groups, showed relatively strong toxicity toward RAW 264.7 cells. Additionally, compounds $\mathbf{2}$ and $\mathbf{3}$, which have $S$-biphenyl positions and one or two hydroxyl groups on the benzene ring, showed significant inhibition of HeLa cells. Compounds $\mathbf{4}$ and $\mathbf{5}$, which have relatively low toxicity toward normal cells, suppressed the proliferation and viability of AGS and HeLa cells. In particular, compound 5, with its angeloyl moiety, exhibited a slightly stronger effect on AGS, HeLa, and HT29 cells than compound 4. These results indicate that the stereochemistry, the presence of an angeloyl or a hydroxy group at C-7, and the benzene ring could be key factors of dibenzocyclootadiene-type lignans affecting the cytotoxicity against AGS, HeLa, and HT29 cells.

After treatment of the compounds, the cell nuclei were stained with Hoechst 33258 and PI were observed by fluorescence microscopy, respectively. The treated cells exhibited apoptotic morphology, such as cell shrinkage with DNA condensation, high fluorescence, and formation of the apoptotic body. And the $\mathrm{IC}_{50}$ value represents the concentration of each compound that inhibits cell activity by $50 \%$ (Table 2).

In conclusion, our data reveal that dibenzocyclooctadiene lignans 2-5 from $S$. chinensis fruits can be effective candidates as anticancer materials for stomach, cervical, and colon cancers.

\section{Supplementary information}

Supplementary information accompanies this paper at https://doi. org/10.1186/s13765-020-00524-y.

Additional file 1: Table S1. ${ }^{1} \mathrm{H}$ - and ${ }^{13} \mathrm{C}-\mathrm{NMR}$ data of schisandrin $\mathrm{A}(\mathbf{1})$ (600 MHz, $\mathrm{CDCl}_{3}$ ). Table S2. ${ }^{1} \mathrm{H}$ - and ${ }^{13} \mathrm{C}-\mathrm{NMR}$ data of (-)-gomisin $\mathrm{K} 1$ (2) $\left(600 \mathrm{MHz}, \mathrm{CDCl}_{3}\right)$. Table S3. ${ }^{1} \mathrm{H}$ - and ${ }^{13} \mathrm{C}$-NMR data of gomisin J (3) $(600$ $\left.\mathrm{MHz}, \mathrm{CDCl}_{3}\right)$. Table S4. ${ }^{1} \mathrm{H}$ - and ${ }^{13} \mathrm{C}-\mathrm{NMR}$ data of gomisin $\mathrm{A}(\mathbf{4})(600 \mathrm{MHz}$, $\mathrm{CDCl}_{3}$ ). Table S5. ${ }^{1} \mathrm{H}$ - and ${ }^{13} \mathrm{C}-\mathrm{NMR}$ data of schisandrin (6) $(600 \mathrm{MHz}$, $\left.\mathrm{CDCl}_{3}\right)$. Table S6. ${ }^{1} \mathrm{H}$ - and ${ }^{13} \mathrm{C}-\mathrm{NMR}$ data of gomisin C (7) $\left(600 \mathrm{MHz}_{1} \mathrm{CDCl}_{3}\right)$

\section{Acknowledgements}

This work was supported by the "Cooperative Research Program for Agriculture Science \& Technology Development” (Project no. PJ01420403), Rural Development Administration, Republic of Korea.

\section{Authors' contributions}

S-KC, Y-GL, and N-IB planned the study and wrote the paper. SKC, Y-GL, H-GK, $\mathrm{DHY}, \mathrm{D}-\mathrm{YL}$, and $\mathrm{N}-\mathrm{IB}$ isolated lignans. S-KC and Y-GL identified all lignans. RBW and $Y$-JK evaluated isolated compounds for cytotoxicity. All authors read and approved the final manuscript.

\section{Funding}

RDA (Project No. PJ01420403) funded this study.

Availability of data and materials

The data and materials used in this study are available under permission from the corresponding author on reasonable request.

\section{Competing interests}

There are no conflicts to declare.

\section{Author details}

${ }^{1}$ Graduate School of Biotechnology and Department of Oriental Medicine Biotechnology, Kyung Hee University, Yongin 17104, Republic of Korea.

2 Department of Herbal Crop Research, National Institute of Horticultural and Herbal Science, RDA, Eumseong 27709, Republic of Korea.

Received: 26 April 2020 Accepted: 13 July 2020

Published online: 18 July 2020 


\section{References}

1. Lee SI (1981) Herbal Medicine. Korea, SooSeoWon, p 172

2. An RB, Oh SH, Jeong GS, Kim YC (2006) Gomisin J with protective effect against $t$-BHP-induced oxidative damage in HT22 cells from Schizandra chinensis. Nat Prod Sci 12:134-137

3. Shin SY, Lee J, Gil HN, Jung YJ, Kim GL, Kang GH, Lim Y (2018) Schisandra chinensis inhibiting TGF $\beta$-induced activation of hepatic stellate cells. Appl Biol Chem 61:607-616

4. Zhu L, Li B, Liu X, Huang G, Meng X (2015) Purification of six lignans from the stems of Schisandra chinensis by using high-speed counter-current chromatography combined with preparative high-performance liquid chromatography. Food Chem 186:146-152

5. Nakajima K, Taguchi H, Ikeya Y, Endo T, Yosioka I (1983) Constituents of Schizandra chinensis Baill. XIII. Quantitative analysis of lignans in the fruits of Schizandra chinensis Baill. by high performance liquid chromatography. J Pharm Soc Jpn 103:743-749

6. Suh WS, Park SY, Min BS, Kim SH, Song JH, Shim SH (2014) The antiproliferative effects of compounds isolated from Schisandra chinensis. Korean J Food Sci Technol 46:665-670

7. Lin S, Fujii M, Hou DX (2008) Molecular mechanism of apoptosis induced by schizandrae-derived lignans in human leukemia HL-60 cells. Food Chem Toxicol 46:590-597

8. Min HY, Park EJ, Hong JY, Kang YJ, Kim SJ, Chung HJ, Kang SS (2008) Antiproliferative effects of dibenzocyclooctadiene lignans isolated from Schisandra chinensis in human cancer cells. Bioorg Med Chem Lett 18:523-526

9. Gnabre J, Unlu I, Chang TC, Lisseck P, Bourne B, Scolnik R, Jacobsen NE Bates R, Huang RC (2010) Isolation of lignans from Schisandra chinensis with anti-proliferative activity in human colorectal carcinoma: structureactivity relationships. J Chromatogr B 878:2693-2700

10. Lee YG, Rodriguez I, Nam YH, Gwag JE, Woo SH, Kim HG, Ko JH, Hong BN, Kang TH, Baek NI (2019) Recovery effect of lignans and fermented extracts from Forsythia koreana flowers on pancreatic islets damaged by alloxan in zebrafish (Danio rerio). Appl Biol Chem 62:7

11. Lee YG, Lee DG, Gwag JE, Kim MS, Kim MJ, Kim HG, Ko JH, Yeo HJ, Kang SH, Baek NI (2019) A 1,1'-biuracil from Epidermidibacterium keratini EPI-7 shows anti-aging effects on human dermal fibroblasts. Appl Biol Chem 62:14

12. Choi DH, Hwang HS (2019) Anti-inflammation activity of brazilin in TNF-a induced human psoriasis dermatitis skin model. Appl Biol Chem 62:46

13. Ikeya Y, Taguchi H, Yosioka I, Kobayashi H (1980) The constituents of Schizandra chinensis Baill. VIII. The structures of two new lignans, tigloylgomisin P and angeloylgomisin P. Chem Pharm Bull 28:3357-3361

14. Balusamy SR, Veerappan K, Ranjan A, Kim YJ, Chellappan DK, Dua K, Lee $J$ H, Perumalsamy H (2020) Phyllanthus emblica fruit extract attenuates lipid metabolism in 3T3-L1 adipocytes via activating apoptosis mediated cell death. Phytomed 66:153129

15. Seo SM, Lee HJ, Park YK, Lee MK, Park JI, Paik KH (2004) Lignans from the fruits of Schizandra chinensis and their inhibitory effects on dopamine content in PC12 cells. Nat Prod Sci 10:104-108

16. Ikeya Y, Taguchi H, Yosioka I, Kobayashi H (1979) The constituents of Schizandra chinensis Baill. III. The structures of four new lignans, gomisin $\mathrm{H}$ and its derivatives, angeloyl-, tigloyl- and benzoyl-gomisin $\mathrm{H}$. Chem Pharm Bull 27:1576-1582

17. Ikeya Y, Taguchi H, Yosioka I (1978) The constituents of Schizandra chinensis BAILL. The structures of three new lignans, angeloylgomisin $\mathrm{H}_{\text {, }}$ tigloylgomisin $\mathrm{H}$ and benzoylgomisin $\mathrm{H}$, and the absolute structure of schizandrin. Chem Pharm Bull 26:328-331

18. Ikeya Y, Taguchi H, Yosioka I, Kobayashi H (1979) The constituents of Schizandra chinensis Baill. I. Isolation and structure determination of five new lignans, gomisin A, B, C, F and G, and the absolute structure of schizandrin. Chem Pharm Bull 27:1383-1394

19. Ikeya Y, Sugama K, Okada M, Mitsuhashi H (1991) Two lignans from Schisandra sphenanthera. Phytochem 30:975-980
20. Zhao XM, Guo FJ, Li YM, Zhu DY (2012) Two new lignans from Celastrus flagellaris Rupr. J Asian Nat Prod Res 14:159-164

21. Lee YG, Lee H, Ryuk JA, Hwang JT, Kim HG, Lee DS, Kim YJ, Yang DC, Ko BS, Baek NI (2019) 6-Methoxyflavonols from the aerial parts of Tetragonia tetragonoides (Pall.) Kuntze and their anti-inflammatory activity. Bioorg Chem 88:102922

22. Li G, Lee CS, Woo MH, Lee SH, Chang HW, Son JK (2004) Lignans from the bark of Machilus thunbergii and their DNA topoisomerases I and II inhibition and cytotoxicity. Biol Pharm Bull 27:1147-1150

23. Szopa A, Ekiert R, Ekiert H (2017) Current knowledge of Schisandra chinensis (Turcz.) Baill. (Chinese magnolia vine) as a medicinal plant species: a review on the bioactive components, pharmacological properties, analytical and biotechnological studies. Phytochem Rev 16:195-218

24. Sarin E, Dall'Acqua S, Šmejkal K, Šlapetová T, Innocenti G, Carrara M (2014) Molecular mechanisms of antiproliferative effects induced by Schisandraderived dibenzocyclooctadiene lignans $(+)$-deoxyschisandrin and (-)-gomisin N in human tumour cell lines. Fitoterapia 98:241-247

25. Wang JR, Kurta'n T, Ma'ndi A, Guo YW (2012) Structure and absolute stereochemistry of nortriterpenoids from Schisandra chinensis (Turcz.) Baill. Eur J Org Chem 28:5471-5482

26. Kee JY, Han YH, Mun JG, Park SH, Jeon HD, Hong SH (2018) Gomisin a suppresses colorectal lung metastasis by inducing AMPK/P38-mediated apoptosis and decreasing metastatic abilities of colorectal cancer cells. Front Pharmacol 9:986

27. Sobierajska E, Konopka M, Janaszewska A, Piorecka K, Blauz A, KlajnertMaculewicz B, Stanczyk M, Stanczyk WA (2017) Unusual Enhancement of Doxorubicin Activity on Co-Delivery with Polyhedral Oligomeric Silsesquioxane (POSS). Materials 10:559

28. Florou D, Patsis C, Ardavanis A, Scorilas A (2013) Effect of doxorubicin, oxaliplatin, and methotrexate administration on the transcriptional activity of BCL-2 family gene members in stomach cancer cells. Cancer Biol Ther 14:587-596

29. Sadeghi-Aliabadi H, Mosavi H, Mirian M, Kakhki S (2012) Zarghi A (2012) The cytotoxic and synergistic effects of flavonoid derivatives on doxorubicin cytotoxicity in Hela, MDA-MB-231, and HT-29 cancer cells. Iran J Toxicol 5:558-564

30. Waziri PM, Abdullah R, Yeap SK, Omar AR, Kassim NK, Malami I, How CW, Etti IC, Abu ML (2016) Clausenidin induces caspase-dependent apoptosis in colon cancer. BMC Complement Altern Med 16:256

31. Atashpour S, Fouladdel S, Movahhed TK, Barzegar E, Ghahremani MH, Ostad SN, Azizi E (2015) Quercetin induces cell cycle arrest and apoptosis in $\mathrm{CD}_{133^{+}}$cancer stem cells of human colorectal HT29 cancer cell line and enhances anticancer effects of doxorubicin. Iran J Basic Med Sci 18:635

32. Chen F, Zhuang M, Zhong C, Peng J, Wang X, Li J, Chen Z, Huang Y (2015) Baicalein reverses hypoxia-induced 5-FU resistance in gastric cancer AGS cells through suppression of glycolysis and the PTEN/Akt/HIF-1a signaling pathway. Oncol Rep 33:457-463

33. Jayaprakasam B, Zhang Y, Nair MG (2004) Tumor cell proliferation and cyclooxygenase enzyme inhibitory compounds in Amaranthus tricolor. J Agric Food Chem 52:6939-6943

\section{Publisher's Note}

Springer Nature remains neutral with regard to jurisdictional claims in published maps and institutional affiliations. 